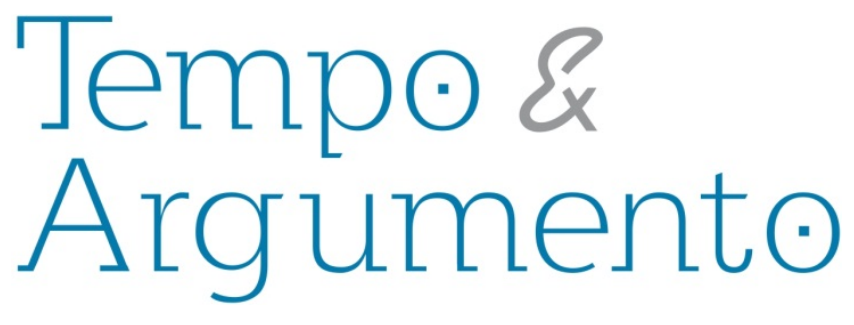

\title{
A Revolução de Outubro na história do século XX
}

\section{Resumo}

Evocado em 1848 por Marx e Engels, o espectro do comunismo encarnou-se em 1871 na Comuna de Paris. Nas décadas seguintes, a perspectiva da conquista do poder pela classe operária deslocou-se para a Alemanha. Desde 1907, a II Internacional mobilizara-se contra a guerra. Quando esta eclodiu, em 1914, a maioria dos dirigentes social-democratas dos países beligerantes aderiu ao patriotismo belicoso. Lênin fazia parte da minoria que condenou a carnificina, explicando-a pela transformação imperialista do modo capitalista de produção. Em fevereiro de 1917 o povo russo derrubou o Czar, mas não conseguiu nem a paz nem a terra. Em outubro 1917, os sovietes conquistaram o poder. Entre 1918 e 1924, sucessivos levantes proletários abalaram a Europa devastada e dizimada pela guerra. A Internacional Comunista foi fundada em 1919 para coordenar, a partir da Rússia Soviética, as lutas operárias e anticoloniais. Eles aprofundaram-se na Ásia, com a China em plena ebulição. Durante as décadas seguintes, até o final do terceiro quarto do século $X X$, os comunistas estiveram na linha de frente dos combates revolucionários em escala mundial.

Palavras-chave: Guerra. Lenin. Comunismo. Sovietes. Internacional.

\section{Para citar este artigo:}

JOÃO QUARTIM DE MORAES. A Revolução de Outubro na história do século XX. Tempo e

Argumento, Florianópolis, v. 10, n. 23, p. 381 - 412, jan./mar. 2018.

\section{DOI: $10.5965 / 2175180310232018381$}

http://dx.doi.org/10.5965/2175180310232018381

\author{
João Carlos Kfouri Quartim de Moraes \\ Doutor em Ciência Política pela Fondation \\ Nationale de Science Politique da Academia \\ de Paris. Professor titular aposentado, \\ colaborador do Departamento de \\ Filosofia da Unicamp. \\ Campinas - SP - BRASIL \\ jqmoraes@gmail.com
}




\title{
The Revolution of October in the history of the 2oth century
}

\begin{abstract}
Announced in 1848 by Marx and Engels, the specter of communism incarnated in 1871 in Paris Commune. In the following decades, the prospect of conquest of power by the working class went to Germany. Since 1907, the II International had mobilized against the war. When it broke out in 1914, most of the social democratic leaders of warring countries adhered to the bellicose patriotism. Lenin was part of the minority who condemned the carnage, explaining it by the imperialist transformation of capitalist mode of production. In February 1917 the Russian people overthrew the Tsar, but didn't obtain nor peace nor land. In October 1917, the Soviets won power. Between 1918 and 1924, successive proletarian uprisings have shaken Europe devastated and decimated by war. The Communist International was founded in 1919 to coordinate, from the Soviet Russia, the workers' and anti-colonial struggles. They deepened in Asia, with China in full boil. During the following decades, until the end of the third quarter of the 20th century, the Communists were on the front line of the fighting revolutionaries on a global scale..
\end{abstract}

Keywords: War. Lenin. Communism. Soviets. International.

\section{Lições da Comuna de Paris}

As expectativas anunciadas no Manifesto Comunista de que a classe operária tomaria o poder nas sociedades onde mais se desenvolvera o modo de produção capitalista configuravam em 1847-8 uma forte possibilidade objetiva. Não era fanfarronice a primeira frase do texto: "um espectro perambula pela Europa: o espectro do comunismo". Menos de um quarto de século depois, a Comuna de Paris veio incarnar este espectro. Como não a considerar a confirmação de que a tomada do poder político estava inscrita nas linhas de força do movimento histórico? 
No entanto, Marx e Engels manifestaram, tanto publicamente quanto em sua correspondência, muita inquietação diante das "circunstâncias extremamente difíceis em que se encontrava colocada a classe operária francesa", sobretudo perante a perspectiva de que a bancarrota política e militar do imperador Napoleão, o pequeno, "estimulasse a 'loucura desesperada' de tentar 'derrubar o novo governo' quando o inimigo golpeia quase nas portas de Paris'. [...] Os operários franceses devem cumprir seu dever de cidadãos; mas eles não devem porém se deixar arrastar pelos souvenirs nacionais de 1792" (MARX, 1968, p. 289). Estas ponderações se encontram no segundo Pronunciamento da Internacional sobre a guerra franco-alemã, datada de 9 de setembro de 1870. Entrementes, as secções parisienses da Internacional haviam lançado um manifesto cujo "tom patrioteiro (chauvin) mostra quanto os trabalhadores franceses ainda estavam sob o domínio da fraseologia vazia e confirma todas as apreensões de Marx e de Engels" (MARX, 1968, Introdução dos editores, p. 10-11).

Entretanto, a partir da jornada revolucionária de 18 de março de 1871, quando o proletariado parisiense tomou o poder na capital e desencadeou-se a guerra civil entre, de um lado, a Guarda Nacional e os operários de Paris e, do outro, as tropas remanescentes do exército imperial, que obedeciam às ordens da alta burguesia instalada em Versalhes, Marx e Engels fizeram a solidariedade com a Comuna passar adiante de qualquer outra consideração, como mostram os textos que escreveram durante a febril agitação do grande combate histórico ${ }^{3}$. Têm especial interesse as ponderações de Marx em sua correspondência com Ludwig Kugelmann, o qual, em carta de 15 de abril de 1871, Ihe expressara sua angústia perante as previsíveis consequências de uma provável derrota:

\footnotetext{
${ }^{1}$ Um "governo de defesa nacional", controlado por políticos da burguesia, tendo à frente o ignóbil Thiers tinha substituído Napoleão, o pequeno.

${ }^{2}$ A alusão de Marx aos souvenirs (em itálico no original) de 1792 remete à palavra de ordem "a pátria está em perigo", com a qual o povo se mobilizou e repeliu os exércitos da reação absolutista que atacavam a França, com isso salvando a República. Marx alerta contra a transposição automática desta palavra de ordem à situação de 1870 .

${ }^{3}$ Entre os escritos que Marx consagrou à Comuna estão (ou estavam, uma vez que quase todas foram perdidas) as cartas diretamente enviadas a dirigentes do proletariado revolucionário, três cartas preservadas para correspondentes alemães, dois "ensaios de redação" de A guerra civil na França e o Pronunciamento (Adresse) do Conselho Geral da Associação Internacional dos Trabalhadores (AIT, mais conhecida por I Internacional), o primeiro redigido provavelmente em abril e início de maio de 1871, o segundo antes do massacre desencadeado em 21 de maio, já que Marx nele se refere ao previsivelmente trágico desfecho como ainda não tendo ocorrido (diz "se eles vencerem" referindo-se a Thiers e sócios) e, enfim, o Pronunciamento, escrito entre 21 e 30 de maio, durante e logo após a "semana sangrenta".
} 
A derrota privará novamente o movimento operário de seus chefes, por tempo bastante longo. Não subestime esta desgraça! Em minha opinião o proletariado tem no momento muito mais necessidade de educação do que da luta com armas na mão. Imputar o insucesso a um acaso qualquer não é recair no erro que o 18 Brumário censura de maneira tão convincente nos pequenos burgueses? ${ }^{4}$ (MARX, 1968, p.15)

Marx replicou em 17 de abril:

Seria evidentemente muito cômodo fazer a história se só devêssemos travar a luta com chances infalivelmente favoráveis. De outro lado, esta história seria de natureza muito mística se os 'acasos' não desempenhassem nela nenhum papel. Estes casos fortuitos entram naturalmente na marcha geral da evolução e ficam compensados, por sua vez, por outros acasos. Mas a aceleração ou a desaceleração dependem muito de 'acasos' semelhantes, entre os quais figura o 'acaso' do caráter dos chefes [...]. (MARX, ENGELS, 1971, p. 268).

Dez anos mais tarde, em carta que enviou em 22 de fevereiro de 1881 à militante social-democrata holandesa F. Domela-Nieuwenhuls, ele comentou a experiência revolucionária de 1871 em termos críticos:

[...] abstração feita de que se tratava de uma simples sublevação de uma cidade em condições excepcionais, a maioria da Comuna não era socialista e nem podia sê-lo. Com um mínimo de bom senso, ela poderia entretanto ter obtido de Versalhes um acordo útil a toda a massa do povo, única coisa que era possível atingir naquele momento. Se tivesse se apropriado do Banco da França, ela teria logrado assustar os falastrões de Versalhes. (MARX, ENGELS, 1971, p. 348).

Em 1895, ano de sua morte, Engels referiu-se uma vez mais à Comuna de Paris, na Introdução a As lutas de classe na França 1848-1850, coletânea de artigos de Marx que até então não tinham sido reunidos em forma de livro. Com um olho posto nos franceses e outro nos alemães, ele discute a tática do movimento operário à luz de meio século de combates, de Paris em 1848 e 1871 a Berlim em 1895:

\footnotetext{
${ }^{4}$ Texto citado na introdução de Marx, 1968, p. 15.
} 
Com a Comuna de Paris, acharam que o proletariado combativo estava definitivamente enterrado. Mas, ao contrário, é da Comuna e da guerra franco-alemã que data seu mais formidável desenvolvimento. A completa transformação de todas as condições da guerra pelo recrutamento de toda a população apta a empunhar as armas em exércitos cujos efetivos se contam por milhões, as armas de fogo, os obuses e os explosivos de efeito desconhecido até então [...] puseram bruscamente fim ao período das guerras bonapartistas e asseguraram o desenvolvimento industrial pacífico, tornando impossível qualquer guerra que não seja uma guerra mundial de inédita crueldade e cujo desfecho seria absolutamente incalculável” (ENGELS, 1974, p. 22-23).

No horizonte histórico da Europa de 1895, parecia razoável supor que o poder destrutivo das novas armas exerceria efeito dissuasivo sobre o militarismo das potências europeias, exorcizando o horrível espectro do triunfo universal da morte. As novas armas dissuadiriam também o recurso à insurreição por parte das massas proletárias. "Outrora, havia as relativamente pouco eficazes balas e obuses da artilharia; atualmente há os obuses de percussão dos quais basta um só para estraçalhar a melhor barricada" (ENGELS, 1974, p. 29). O novo urbanismo dos grandes bulevares tinha também contribuído para tornar bem mais difíceis os combates de rua. "Seria insensato o revolucionário que escolhesse os novos distritos operários do norte e do este de Berlim para um combate de barricadas" (ENGELS, 1974, p. 30).

Entrementes, após resistir vitoriosamente aos doze anos de ilegalidade (18781890) a que os tinha condenado a lei de exceção imposta por Bismarck em 1878, os socialdemocratas alemães obtiveram, já em 1890, a maior porcentagem dos votos para o Reichstag (19,8\%); em 1893, atingiram 23,4\%. A possibilidade de levar adiante o combate pelo socialismo pela via da luta de massas e da disputa do voto pouparia à população o sempre alto custo de um confronto armado. Como não saudar essa perspectiva? Mas o justificável otimismo de Engels a propósito da participação nas eleições não o fez perder de vista a possibilidade de conjunturas históricas mais sombrias. Sabia muito bem que, no plano dos princípios, as alternativas insurreição ou voto, luta armada ou luta pacífica são táticas, uma vez que concernem aos meios (forma de luta e de organização) e não aos fins (o programa comunista), mas também que meios e fins se interpenetram dialeticamente na lógica da ação, tornando fugidia e imprecisa a linha divisória entre 
decisão tática e objetivo programático. Só a situação concreta pode indicar a melhor tática a seguir. Por isso mesmo, ele evita fórmulas peremptórias e generalizações apressadas, criticando os que apresentavam as eleições e a eventual conquista da maioria parlamentar como via decisiva, senão única, para o socialismo.

No horizonte de 1848, estas expectativas configuravam uma possibilidade histórica perfeitamente plausível, porque baseada na tendência objetiva de aprofundamento e de expansão da contradição entre trabalho e capital. Mas às tendências se opõem contratendências. Vivendo longos anos na Inglaterra, Marx e sobretudo Engels puderam constatar o que chamaram, sem eufemismo e até com certo amargor, de "aburguesamento" de camadas da classe operária. Assim se expressou Engels, com efeito, numa carta que escreveu a Marx em 7 de outubro de 1857, citada por Lênin:

[...] o proletariado inglês se aburguesa cada vez mais; parece que esta nação, burguesa entre todas, quer chegar a ter, ao lado de sua burguesia, uma aristocracia burguesa e um proletariado burguês. Evidentemente, por parte de uma nação que explora o universo inteiro, isso é até certo ponto lógico. (citado por LÊNIN, 1960a, p. 306)

Um quarto de século depois, em 12 de setembro de 1882, Engels reiterou esta constatação em carta a Kautsky:

Você me pergunta o que pensam os operários ingleses da política colonial. A mesma coisa que eles pensam da política em geral. Não há, aqui, partido operário; só há radicais conservadores e liberais. Quanto aos operários, eles desfrutam com a maior tranquilidade [...] do monopólio colonial da Inglaterra e de seu monopólio sobre o mercado mundial. (citado por LÊNIN, 1960a, p. 306)

O emprego do termo monopólio duas vezes na mesma frase a propósito das colônias inglesas e do mercado mundial anuncia a teoria do imperialismo, embora Engels não se sirva desta palavra. Mas o fenômeno social está claramente identificado: ao associar subalternamente as camadas economicamente superiores da classe operária dos países dominantes a suas burguesias respectivas, o monopólio colonial gerou uma contratendência à polarização da luta de classes entre trabalhadores e capitalistas, na 
qual se baseavam as expectativas do Manifesto. Num artigo publicado em janeiro de 1916, mesmo ano em que formulou a teoria do imperialismo, Lênin não se limitou a denunciar "aqueles que votaram pelos créditos de guerra, entraram para os ministérios e advogaram a ideia da defesa da pátria em 1914-1915"; examinou o significado econômico desta política e sua ligação com a história das tendências no movimento socialista:

A burguesia de todas as grandes potências trava a guerra com o fim de partilhar e explorar o mundo, com o fim de oprimir os povos. Um pequeno círculo da burocracia operária, da aristocracia operária e de companheiros de jornada pequeno-burgueses podem receber algumas migalhas dos grandes lucros da burguesia. A causa de classe profunda do social-chauvinismo e do oportunismo é a mesma: a aliança de uma pequena camada de operários privilegiados com a "sua" burguesia nacional contra as massas da classe operária (grifado no original). (LÊNIN, 196ob, p.119).

A traição da social-democracia aos solenes compromissos assumidos em Stuttgart e em Basileia de lutar contra a guerra tinha pois seu fundamento objetivo na diferenciação econômico-social no interior da classe operária dos países capitalistas dominantes. Essa diferenciação reforçava-se pela exploração imperialista do planeta. Discernindo uma tendência que iria se configurar plenamente na segunda metade do século XX, Lênin assinala

[...] a diminuição da imigração proveniente dos países imperialistas e o crescimento da imigração, para estes países, de operários vindos de países mais atrasados, onde os salários são mais baixos. [...] Nos Estados Unidos, os imigrantes da Europa central e meridional ocupam os empregos mais mal pagos, enquanto os operários americanos fornecem a mais forte proporção de contra mestres e de operários executando os trabalhos mais bem retribuídos. $O$ imperialismo tende a criar, também entre os operários, categorias privilegiadas que se separam da grande massa do proletariado. (LÊNIN, 1960a, p. 306).

\section{Entre heterodoxia e ortodoxia}

O sentido corrente do termo “ortodoxia", predominantemente pejorativo (= dogma), designa as mentalidades estreitas, temerosas de qualquer ideia diferente

\footnotetext{
${ }^{5}$ Lênin diz "também" entre os operários, porque havia mostrado antes, apoiado em Hobson, as diferenciações que o parasitismo financeiro estabelece no interior da burguesia imperialista.
} 

mesma tese em condições modificadas é ser dogmático.

Diante de fatos novos que Marx e Engels não poderiam ter levado em conta, Lênin discernia, com extraordinária capacidade de articular a universalidade da teoria fundamental com as situações concretas, as teses cuja esfera de validade correspondia a determinadas condições históricas, mas não a outras. Foi, sobretudo, em relação ao Manifesto Comunista que os bolcheviques trouxeram inovações que atualizaram e concretizaram o programa revolucionário formulado em 1848. As duas principais foram o partido de vanguarda (organização revolucionária “de tipo novo”) e a aliança operáriocamponesa.

1- O segundo capítulo do Manifesto, "Proletários e comunistas", após declarar liminarmente que os comunistas não são um partido particular contraposto aos outros partidos operários, assinala que eles se distinguem em dois pontos: nas lutas nacionais eles salientam os interesses comuns de todo o proletariado; eles defendem sempre os interesses do movimento em sua totalidade. Enfatiza em seguida que eles "são na prática a parte (Teil) mais decidida dos partidos operários de todos os países, a que impulsiona todas as outras e, quanto à teoria, eles têm, relativamente à massa restante do proletariado, um discernimento mais avançado das condições, da marcha e dos resultados gerais do movimento proletário" (MARX, ENGELS, 1978, p. 429-430). O quarto capítulo, que é o último e o mais curto, expõe a "posição dos comunistas perante os diferentes partidos de oposição", reiterando a mesma caracterização do segundo capítulo e preconizando apoio a todos os combates revolucionários, inclusive àqueles da revolução burguesa alemã em curso.

Embora sustentem em comum a ideia de posição de vanguarda dos comunistas, não somente em relação à massa do proletariado, mas também aos demais partidos operários, é forte o contraste entre a concepção de partido da Liga dos comunistas, em nome da qual Marx e Engels tinham redigido o Manifesto, e a dos bolcheviques. No Manifesto as questões de organização não são discutidas pela clara razão de que não 
grande obra fundadora, ele se enraizava nas condições concretas do combate revolucionário clandestino sob a autocracia czarista, mas o alcance da teoria do partido de vanguarda da classe operária, articulado por revolucionários que atuavam permanentemente como uma só vontade segundo os princípios do centralismo democrático, é universal. Diferentemente dos partidos de massa da social-democracia, que se atrelaram à lógica da luta parlamentar, o partidos leninistas não renunciaram nem no plano dos princípios, nem no dos combates concretos, a nenhuma forma de luta. Em 1936-1939, na defesa da República espanhola, violentada pela contrarrevolução clericalfascista do carniceiro Franco e parceiros; em 1941-1945, na resistência ao terror nazifascista, os partidos leninistas constituíram a espinha dorsal da luta operária e popular.

2- No Manifesto Comunista, o camponês (der Bauer) é apresentado, como os outros estamentos médios (Mittelstände), como "conservadores, mais ainda, reacionários, já que tentam virar para trás a roda da História” (MARX, ENGELS, 1978, p. 427). A ortodoxia do próprio Marx, entretanto, era dialética: bem sabemos que ele nunca foi um marxista dogmático. Em dois escritos importantes de seus últimos anos de vida, ele relativizou a avaliação do Manifesto, que relegava o camponês à condição de fóssil histórico, declarando com ênfase na Resposta a Mikhailovsky (novembro de 1877) que o desenvolvimento do capitalismo não acarretava inelutavelmente em toda parte a dissolução das aldeias camponesas (MARX, 1968, p.1552-1555). Ele foi mais longe na correspondência com Vera Zasulich (fevereiro/março de 1881). Em especial, na carta de 8 de março de 1881, após ter lembrado que no Capital a "fatalidade histórica" da "expropriação dos cultivadores" foi " expressamente restringida aos países da Europa ocidental", Marx concordou com a tese de que a comuna rural "é o ponto de apoio da regeneração social na Rússia" (MARX, ENGELS, 1971, p. 349-350).

Em sentido contrário, empenhado em salientar, contra o socialismo agrarista dos populistas, o papel de vanguarda da classe operária na luta contra a autocracia czarista, 
era inexorável. Teria ele defendido a ortodoxia marxista mais do que o próprio Marx? Naquele contexto e naquele momento, sim. Mas como a de Marx, a ortodoxia de Lênin era dialética, e sua dialética, materialista. Ele estava certo ao pôr em evidência o avanço do capitalismo na economia russa. Nem tanto, porém no que concerne a seus efeitos desagregadores sobre as comunidades camponesas. Elas foram sem dúvida afetadas pela crescente monetarização das trocas, mas em ritmo lento, adaptando-se em graus diversos às relações mercantis em expansão.

Lênin não perdeu de vista, entretanto, as massas camponesas em luta pela terra, portanto contra o czarismo pela supressão dos restos feudais. Já em seu projeto de programa agrário de 1899, no programa agrário de 1903 e sobretudo no de 1907, ele completou dialeticamente a tese "ortodoxa" sobre a inevitabilidade do desenvolvimento do capitalismo na Rússia com o "heterodoxo" apoio da classe operária ao imenso campesinato russo. A revolução de 1905 confirmou amplamente o acerto dessa linha política, que se consolidou durante o período de feroz repressão policial dos anos seguintes, e depois durante a retomada da mobilização popular até as vésperas da guerra de 1914.

\section{4: barbárie da civilização europeia}

Confirmando o otimismo de Engels ao comemorar na Introdução de 1895 o avanço político do proletariado alemão, em 1912 a social-democracia obteve notável vitória eleitoral, tornando-se, com 34,8\% dos votos e 397 deputados, o maior partido do Reichstag. Paralelamente, porém, contrariando sua expectativa sobre a paz, a grande indústria gerou trustes e cartéis monopolistas, empenhados, com apoio da máquina bélica de seus Estados respectivos, em tenaz disputa pelos territórios coloniais e pelo controle do mercado mundial. Essa disputa pela supremacia planetária exacerbava as contradições entre as grandes potências imperialistas, fazendo pairar no horizonte o 
extraordinário em Basileia, os partidos da II Internacional adotaram, num clima carregado de entusiasmo, mas também de apreensão, um manifesto em que assumiam o compromisso solene de lutar contra a guerra. Nesse manifesto foi incluída uma resolução que o ainda não muito conhecido Vladimir Ilitch Lênin apresentara em 1907 ao Congresso anterior da Internacional em Stuttgart, de que, caso a guerra fosse desencadeada, os partidos socialistas deveriam fazer da situação caótica que ela criaria o fermento da revolução socialista.

Alguns dirigentes da II Internacional honraram este compromisso. O francês Jean Jaurès, orador principal no Congresso de Basileia junto com a alemã Clara Zetkin, pôs-se à frente da luta para barrar o avanço do belicismo, que em nome da defesa da pátria exacerbava o ódio entre os povos. Ele foi assassinado por um extremista de direita na tarde de 31 de julho de 1914, quando a guerra explodia. Na Alemanha, além de Zetkin, destacaram-se nesta luta Rosa Luxemburgo, Karl Liebknecht e Wilhelm Pieck. Majoritariamente, porém, deflagrada a guerra, os dirigentes da maioria oportunista da social-democracia desarmaram politicamente a classe operária, passando a pregar, em nome do patriotismo, o resignado caminho do matadouro. Com honrosas e corajosas exceções, os deputados da social-democracia renegaram os solenes compromissos assumidos perante a Internacional, votando em seus respectivos parlamentos a favor dos créditos bélicos e apoiando os governos de seus países na transformação da força de trabalho em carne de canhão. A social-democracia alemã saiu na frente, aprovando no Reichstag o orçamento de guerra do Kaiser. Na França, o comportamento mais lamentável foi o de Jules Guesde, ao lado de Jaurès o maior nome do socialismo francês. Ele não somente aderiu à "Union sacrée" (bloco bélico de todos os partidos para enfrentar a Alemanha), mas foi ministro do governo de guerra de 1914 a $1916^{6}$. Apesar de carregar o epíteto de renegado, Kautsky não foi tão longe na trilha do social-patriotismo.

\footnotetext{
${ }^{6}$ Contrastamos as trajetórias de Jaurès e de Guesde em Quartim de Moraes, 2007, p. 139-141. Lá notamos, a propósito de Guesde, que após se opor a qualquer colaboração com governos burgueses, em nome da pureza revolucionária, aceitou participar, junto com outros "social-patriotas", do governo dito de "União Sagrada" que dirigiu a França beligerante durante a horrível carnificina de 1914-1918.
} 
As exaltantes esperanças expressas no Manifesto, de que a classe operária europeia iria se libertar do capital e, libertando-se, emanciparia a humanidade, encontraram seu ponto de inflexão no dilúvio de fogo, chumbo, aço e explosivos que a partir de julho/agosto de 1914 mudou catastroficamente o curso da história mundial. Até 1914, como notou Luigi Cortesi, "a lógica da transição para o socialismo estava incluída na própria lógica do desenvolvimento capitalista, que em certo sentido a garantia e a revolução socialista eclodiria da plenitude daquele desenvolvimento" ${ }^{77}$ (CORTESI 1997, p. 244). Lênin até então também partilhava desta hipótese otimista da II Internacional, como bem mostrou num importante escrito de fins de 1913, "Notas críticas sobre a questão nacional":

a tendência histórica universal do capitalismo à destruição das barreiras nacionais, a assimilar as nações, uma tendência que se torna de década em década mais vigorosa e constitui um dos fatores principais para a transformação do capitalismo em socialismo. Acrescenta: O marxismo substitui a cada nacionalismo o internacionalismo, a fusão de todas as nações numa unidade superior, que se desenvolve sob nossos olhos, com cada novo quilômetro de ferrovia, com cada novo trust internacional, com cada nova associação operária (LÊNIN, 1959, p. y21).

Compreende-se o impacto que a imensa tragédia desencadeada durante a última semana de julho de 1914 (bombardeio de Belgrado pelos austríacos, mobilizações gerais e declarações multilaterais de guerra dos dois lados) exerceu sobre o pensamento e a ação de Lênin. A expectativa de que quanto mais o capitalismo se desenvolvesse, mais o proletariado se fortaleceria e mais se aproximaria a hora do socialismo, carbonizava-se no mar de lava e de magma ensanguentados que estava recobrindo o continente europeu. A traição da II Internacional às solenes resoluções antibelicistas adotadas nos Congressos de Stuttgart (1907) e de Basileia (1912) traumatizou-o moral e intelectualmente. Ele sabia perfeitamente que uma ala poderosa da social-democracia defendia não só a colaboração com a burguesia, mas também com o colonialismo, apresentando como obra civilizatória a opressão e saqueio dos povos coloniais. Não esperava, porém, que a grande maioria dos partidos e dos dirigentes da Internacional, inclusive Kautsky, o mais respeitado

\footnotetext{
7 O livro em que está publicado este estudo de Cortesi é resultado de um colóquio transcorrido em janeiro de 1994 em Urbino, Itália. Comentamos os principais estudos dessa obra coletiva em Quartim de Moraes, 2000, pp. 133-144.
} 
continuador intelectual de Marx e Engels, se acumpliciasse com o fato consumado da conflagração geral. (Somente os bolcheviques, ao lado dos partidos social-democratas da Sérvia e da Bulgária, recusaram-se a caucionar a carnificina). Afinal, os Congressos de Stuttgart e de Basileia haviam mostrado a amplitude e a força de convicção da mobilização operária contra a guerra. Jean Jaurès, em particular, tinha insistido muito junto aos trabalhadores para que eles não se deixassem levar pela confiança desmobilizadora na marcha inexorável do mundo para o socialismo, que os impediria de perceber os graves perigos do momento.

Não foi, pois, o desencadeamento da guerra em si mesmo, mas a capitulação dos dirigentes da ala majoritária da Internacional perante seus governos respectivos que caiu como um raio sobre Lênin e os demais revolucionários. Mas esta traição não explica tudo. A ilusão de que a guerra seria rápida contribuiu, ao lado dos ódios nacionais, para reduzir a resistência operária à lógica perversa do belicismo. O fato de que a massa dos trabalhadores, submetida a um rígido enquadramento militar, tenha se deixado empurrar para as enormes carnificinas do front mostra antes de mais nada o brutal poderio da máquina do Estado e a lógica implacável da barbárie civilizada. ${ }^{8}$ As deserções eram punidas com penas severíssimas, frequentemente com fuzilamento. ${ }^{9}$ A hecatombe foi pavorosa: morreram na grande guerra de 1914-1918, segundo os dados oficiais, 9.720.453 combatentes e 8.871 .248 civis.

\footnotetext{
${ }^{8}$ Domenico Losurdo assinalou uma das mais infames perversidades da barbárie bélica: o uso não somente de seus próprios povos, mas também das populações coloniais africanas e asiáticas como carne para canhão. Infâmia na infâmia, em vez de manifestar gratidão a esses homens arrancados de suas terras natais para serem alvos da metralha, da artilharia e dos gases tóxicos numa guerra com a qual não tinham estritamente nada a ver, o filósofo liberal Benedetto Croce lamentou que a França tivesse festejado "selvagens bárbaros, senegaleses e gurkas indianos que pisavam sua doce terra". Ver D. Losurdo, 2006, p. 33, que remete a Croce, 1930, p.143.

9 Um dos episódios mais horríveis dessa barbárie em escala continental foi a "batalha imunda" do Chemin des Dames, iniciada em 16 de abril de 1917 (a expressão é de Gilles Lapouge, correspondente na França do jornal O Estado de São Paulo): "O Chemin des Dames foi duas vezes infame. Em primeiro lugar, por causa da demência vaidosa do general Nivelle, que lançou ondas de soldados contra as implacáveis posições alemãs, provocando em 15 dias de 60 mil a 70 mil mortes. Inutilmente. Esses soldados, esgotados por três anos de guerra, doentes, vivendo como ratos na lama das trincheiras, feridos, desprezados por seus chefes, revoltaram-se [...] Segunda ignomínia: [...] O general Pétain pôs então ordem nas fileiras do Exército e acabou com os motins. Como? Mandando fuzilar 49 soldados" (LAPOUGE, 1998, p. A29). Vale lembrar que, em 1940, o mesmo Pétain capitulou diante da Alemanha e se tornou chefe de um governo fantoche a serviço do III Reich hitleriano.
} 


\section{A grande guerra interimperialista}

Admitindo que tenham sido profundas a surpresa, a decepção e o abatimento de Lênin diante da traição cometida pela II Internacional, ele recuperou sua energia habitual com admirável rapidez, assumindo nesse momento terrível da história da humanidade toda a grandeza de sua estatura. Não se contentando em denunciar a capitulação da Internacional, ele empenhou-se em analisar os fatores objetivos que explicavam a deflagração do confronto bélico generalizado, cuja possibilidade Engels havia discernido, mas considerado improvável.

Em 1916, durante sua permanência na Suíça, para onde tinha sido deportado pelas autoridades germânicas, ele consagrou-se à elaboração de Imperialismo, estágio superior do capitalismo, trabalhando sobre larga documentação e apoiando-se criticamente nas obras do socialista inglês Hobson e do marxista alemão Hilferding (mais tarde assassinado pelos nazistas). Para ter uma ideia do alcance da inflexão teórica imprimida ao marxismo por Lênin nessa obra decisiva, basta notar que a noção de imperialismo não faz parte do vocabulário de Marx e de Engels e que eles empregam o termo colônia em sentido certamente distinto (senão oposto) ao que ele assumirá a partir da Revolução de Outubro. A esse respeito, o marxista estadunidense James O'Connor notou que, além do breve capítulo final do livro I, são muito raras as referências do Capital à economia do colonialismo (O'CONNOR, 1970, p. 107). Para que fosse exato, ele deveria ter esclarecido que no referido capítulo (XXXIII) Marx discute a "teoria moderna da colonização" na perspectiva histórica da expansão planetária do capitalismo, sem sequer se servir do termo colonialismo, que também não figura em seu vocabulário. Seu tema era outro: a condição peculiar dos colonos europeus que tiveram acesso à propriedade da terra, juntando aquilo que o desenvolvimento do capitalismo tendia a separar: a propriedade e o trabalho.

Ao conferir estatuto teórico à transformação imperialista do capitalismo, Lênin permitiu compreender por que era enganosa a hipótese otimista formulada por Engels em 1895. Ela baseava-se explicitamente na ideia de que o desenvolvimento industrial seria pacífico, e portanto que chefes de Estado, parlamentares, generais e círculos dirigentes da burguesia, antevendo as tenebrosas perspectivas de um confronto bélico 
O caráter inovador da obra está já expresso no título: seu conceito fundamental, imperialismo, caracteriza o "estágio superior do capitalismo". Ele resulta de cinco transformações principais do modo capitalista de produção: (1) concentração do processo produtivo, gerando os monopólios; (2) predomínio do capital bancário sobre o industrial, formando a oligarquia financeira; (3) predomínio da exportação de capitais sobre a de mercadorias; (4) divisão econômica do mundo entre os trustes; (5) conclusão da divisão territorial do planeta entre as grandes potências. A análise destas transformações capta a dialética de seu desenvolvimento histórico, notadamente a transformação do quantitativo (acumulação do capital) em qualitativo (capitalismo de monopólios) e a unidade (imperialismo) desse complexo de processos (LÊNIN, 1960a, p. 287). ${ }^{10}$

Entre agosto de 1916 e março de 1917, Lênin tirou as conclusões políticas da teoria que ele vinha de formular, discutindo aprofundada e pormenorizadamente os diferentes aspectos da luta de classes contra a guerra imperialista. A mais inovadora destas conclusões consistiu na compreensão de que na época do imperialismo a revolta dos povos coloniais tendia a se juntar ao combate revolucionário do proletariado:

cometeríamos um erro grave se esquecêssemos de que toda guerra não é senão a continuação da política por outros meios; a guerra imperialista é a continuação da política imperialista de dois grupos de grandes potências e esta política é gerada e alimentada pelo conjunto das relações existentes na época do imperialismo. Mas esta mesma época deve também, necessariamente, gerar e alimentar a política de luta contra a opressão nacional e a política de luta do proletariado contra a burguesia: por conseguinte, ela deve tornar possíveis e inevitáveis, em primeiro lugar as insurreições e as guerras nacionais revolucionárias; em segundo lugar as guerras e os levantes do proletariado contra a burguesia; em terceiro lugar uma fusão destas duas formas de guerras revolucionárias etc. (LÊNIN, 1959, p. 87-88)

\footnotetext{
${ }^{10} \mathrm{~A}$ exposição das cinco principais características da transformação imperialista do capitalismo ocupa boa parte do livro.
} 
Não é preciso insistir em que estão aí delineadas as linhas de força da história mundial no século XX. Tenha ele sido curto ou não, não se pode entendê-lo sem a teoria do imperialismo formulada por Lênin em 1916.

\section{Revolução contra o Capital ou contra o Manifesto?}

Num artigo publicado originalmente no jornal Avanti de 24 de novembro de 1917 e logo em seguida em II Grido del Popolo de 5 de janeiro de $1918^{11}$, Antonio Gramsci deixou um notável registro do impacto do Outubro soviético sobre a esquerda europeia. Já no título ironicamente paradoxal, "La Rivoluzione contro il Capitale", ele enfatiza a singularidade da revolução que acabara de triunfar na Rússia. As boas ironias são as que fazem pensar. Embora injusto com Marx, o artigo tem o mérito de apontar para o componente heterodoxo da Revolução de Outubro. "Contra o Capital" porque “O Capital de Marx era, na Rússia, o livro dos burgueses, mais que dos proletários”. Em dois sentidos pelo menos esta afirmação tem fundamento: (a) eram sobretudo os intelectuais de extração burguesa, principalmente pequeno-burguesa, que o estudavam; (b) predominava entre os leitores russos do Capital uma interpretação fatalista da lógica objetiva da história social, segundo a qual a Rússia teria necessariamente de passar pelo desenvolvimento capitalista antes de que o proletariado pudesse sequer pensar em sua própria revolução.

Mas, prossegue Gramsci (1917), “os fatos superaram as ideologias”. O principal destes fatos era a guerra. Marx tinha "previsto o previsível”. Não podia prever que a guerra europeia "iria ter a duração e os efeitos que teve" e que "três anos de sofrimentos indizíveis, iria suscitar na Rússia a vontade coletiva popular que suscitou”. Uma vontade popular unitária normalmente (é Gramsci que enfatiza o termo) “precisa, para formar-se, de um longo processo de penetração capilar; de uma larga série de experiências de classe"; a anormalidade instaurada pelo dilúvio de chumbo, aço e fogo que se abateu sobre o continente europeu acelerou a história social:

\footnotetext{
${ }^{11}$ Lemos e traduzimos do Archivio Gramsci da Internet. Todas as citações que seguem foram diretamente traduzidas desta fonte.
} 
na Rússia a guerra serviu para destravar as vontades. Estas, através dos sofrimentos acumulados em três anos, se fizeram uníssonas muito rapidamente. $O$ desabastecimento era iminente, a fome, a morte pela fome podia atingir todos, esmagando de um golpe dezenas de milhões de homens. As vontades se fizeram uníssonas, primeiro mecanicamente; ativamente, espiritualmente depois da primeira revolução [de fevereiro].

Resta compreender por que só na Rússia "as vontades se fizeram uníssonas" com ímpeto suficiente para derrubar o poder de Estado que os tangia para a carnificina. As perdas de vidas humanas não foram muito diferentes nos diversos exércitos beligerantes. Os dados mais prováveis registram quase 2 milhões de russos mortos no front, além de 5 milhões de feridos. A França registrou cerca de 1,4 milhão de mortos e 4,2 milhões de feridos; a Alemanha, 2 milhões de mortos e 4,2 milhões de feridos; a Áustria-Hungria, 1,4 milhões de mortos e 3,6 milhões de feridos; a Grã-Bretanha, 960.000 mortos e 2 milhões de feridos; a Itália, 600.000 mortos e 1 milhão de feridos e o Império Otomano, 800.000 mortos. Foi o Exército sérvio, porém, que sofreu a pior hecatombe, imposta pela fúria punitiva dos austro-húngaros: somados, seus 130.000 mortos e 135.000 feridos corresponderam a três quartos de seu efetivo total. Os sofrimentos que a guerra impôs ao povo russo são comparáveis aos dos outros povos atolados "no pântano europeu, lamacento e sangrento" (a expressão é de Lênin); a classe operária, os camponeses e em especial a juventude de todos eles serviram de carne para canhão nos campos de batalha da Europa e do Médio Oriente. Mas por terem afetado todos os países beligerantes com a mesma implacável indiferença, as destruições e misérias trazidas pela guerra não bastam para explicar as duas revoluções russas.

Embora inegável, o nexo entre guerra e revolução não corresponde a uma relação mecânica de causa a efeito. Não é qualquer guerra que abre brechas para o surgimento de situações revolucionárias, mas sobretudo aquelas que trazem consequências caóticas para os países derrotados. Em 1918-1919, ocorreu o inverso: a capitulação do II Reich diante dos franceses derrubou o regime imperial e abriu caminho para o levante spartakista; paralelamente, após o desmantelamento do Império austro-húngaro, uma república soviética foi proclamada na Hungria. Mas enquanto as revoluções populares russas eclodiram em plena guerra, os spartakistas alemães e os sovietes húngaros de Bela Kun 
dirigentes, nomeadamente Karl Liebknecht e Rosa Luxemburgo. Ainda em 1919, os Freikorps também foram empregados no aniquilamento da República Soviética da Baviera. Na Hungria, o exército romeno, com apoio do vitorioso imperialismo francês, encarregou-se (movido, além do ódio ideológico, por ambições territoriais) de esmagar os sovietes de Budapest. A única destas situações revolucionárias que conduziu a classe operária à vitória foi a da Rússia de 1917.

Gramsci (1917) contrastou o caráter espontâneo da revolução de fevereiro 1917 (ela ocorreu "mecanicamente") com a intensa atividade política e organizativa que conduziu "ativamente, espiritualmente" à grande revolução de outubro. Há entre as duas revoluções uma clara relação de antecedente a consequente, cujo suporte foi a vontade popular unitária do povo russo, mas cujo êxito final resultou da lúcida e audaciosa política dos bolcheviques. Estes, segundo Gramsci (1917), "renegam Carlos Marx, afirmam com o testemunho da ação efetivada, das conquistas realizadas, que os cânones do materialismo histórico não são assim tão férreos quanto se poderia pensar e se pensou".

Desnecessário insistir sobre a unilateralidade desta avaliação, mesmo porque faltava a Gramsci neste artigo a reflexão, que ele desenvolveria mais tarde em seus célebres escritos consagrados ao "moderno príncipe", sobre a concepção leninista do partido marxista de vanguarda. Bem sabemos, de resto, que os bolcheviques, longe de renegar Marx, consideravam-se os continuadores do marxismo na Rússia. A ironia maior da tese da "Rivoluzione contro il Capitale" está em que não foi o autor do Capital, e sim o dirigente maior da revolução de outubro que se ateve aos "cânones do materialismo histórico". Seguindo a ortodoxia de Lênin, os bolcheviques inverteram a ironia do paradoxo com que Gramsci expressou a singularidade da revolução russa: eles ficaram com o Capital contra a carta de Marx a Vera Zasulich. Sem dúvida, como ocorria também alhures, havia entre eles os que consideravam a obra de Marx um conhecimento teórico já pronto para ser aplicado, como se aplica um remédio a um doente; outros porém, a 
Seria pedantismo exigir precisão analítica de um artigo escrito em cima dos acontecimentos. Parece-nos, entretanto, que Gramsci teria tido mais razão se em vez de "Rivoluzione contro il Capitale" tivesse falado em "Rivoluzione contro il Manifesto". É neste escrito, não na grande obra econômica, que são fortemente anunciadas as expectativas de que a classe operária tomaria o poder político nas sociedades onde mais avançara o modo de produção capitalista e de que, tomando o poder, ela emanciparia o trabalho e libertaria toda a humanidade dos grilhões da exploração e da opressão.

Gramsci estava certo ao considerar a vontade popular unitária do povo russo, forjada nas privações e horrores da guerra, o fator determinante da dinâmica insurrecional de fevereiro 1917; na de outubro, reconheceu o papel decisivo do bolchevismo. Era plausível, naquele momento, supor que as caóticas consequências sociais da guerra provocariam novos surtos insurrecionais, mas evidentemente a revolução real que vinha de ocorrer ocupava o centro das atenções. Só retrospectivamente, após o exaurimento das lutas revolucionárias que eclodiram na Alemanha e na Hungria no imediato pós-guerra, bem como do "biennio rosso" na Itália, passou a ter sentido perguntar por que a revolução só triunfou na Rússia. Se a concatenação guerra/revolução não explica por si só o triunfo da classe operária russa (que não somente tomou, mas também conservou o poder), fica evidente que a ação de Lênin e dos bolcheviques foi decisiva em outubro 1917. Em fevereiro daquele ano, porém, Lênin estava longe (embora como sempre, seguindo de perto os acontecimentos). Ele e seu partido vinham lutando para transformar a guerra imperialista em guerra de classes. Até que ponto a agitação e propaganda em torno desta meta contribuíram para elevar a combatividade das massas populares tornando unânime sua revolta, só um estudo historiográfico minucioso pode esclarecer.

Certo é que o papel principal na derrubada do czarismo foi do povo russo, notadamente das mulheres, que em Petrogrado enfrentaram famélicas as tropas de choque do Czar. No dia 23 de fevereiro de 1917 (que correspondia a 8 de março no calendário gregoriano), comemorando a Jornada Internacional das Mulheres, operárias, empregadas do comércio e serviços, estudantes, mães promoveram grande manifestação, à qual aderiram 
os operários em greve do complexo industrial Putilof. A mobilização se ampliou; aos protestos por pão e trabalho foram se acrescentando consignas políticas, em especial "Viva a República". No dia 25, cerca de 150.000 operários se concentraram no centro da cidade, suscitando uma primeira fratura das forças militares: um regimento de cossacos recusou-se a atirar no povo desarmado. No dia 26, o Czar deu ordem à guarnição militar de Petrogrado para abrir fogo contra os manifestantes. Mais de cento e cinquenta foram mortos. Perante o sangue derramado, os soldados revoltaram-se contra a tarefa ignóbil que a autocracia decrépita Ihes impunha. Na madrugada de 27 de fevereiro, o regimento da Guarda Preobajenski e os regimentos Litovski, Pavlovski e Volynski rebelaram-se contra seus comandantes, recusando-se a atirar nos trabalhadores. Soldados e operários confraternizaram. Armas foram distribuídas aos insurgentes. No final do dia 27, praticamente todas as unidades militares de Petrogrado haviam passado para o campo da revolução.

\section{Concentração e transferência das contradições}

Com objetividade materialista, Lênin salientou em Que fazer? (1902) o caráter burguês da revolução vindoura, mas com audácia dialética, atribuiu à classe operária posição de vanguarda na luta pela democracia, rompendo com as ideias dominantes na II Internacional, que determinavam mecanicamente o papel político de uma classe por sua posição na base econômica da sociedade. Ele inovava, mas no sentido de desenvolver uma ideia que estava presente no tópico final do Manifesto Comunista, a saber, os efeitos sinergéticos da conjunção das formas capitalistas com as pré-capitalistas de exploração e de opressão em situações revolucionárias. Em 1848, na iminência da revolução burguesa na Alemanha, Marx e Engels consideraram que, por eclodir "em condições mais avançadas da civilização europeia e com um proletariado mais desenvolvido do que tinham a Inglaterra e a França no século XVII e XVIII", ela "pode ser o prelúdio imediato de uma revolução proletária" (MARX; ENGELS, 1978, p. 451).

A previsão não se confirmou naquele momento histórico. A burguesia alemã compôs-se com a nobreza militar feudal prussiana, levando a termo, sob a autoridade de 
confirmação na Rússia. Ela confirmou-se, entretanto, de modo heterodoxo. O caráter profundamente popular da revolução de fevereiro 1917 expressou-se, como em 1905, na formação dos sovietes de operários e de camponeses, muitos destes, como Lênin salientou, "sob o uniforme do soldado". Mas ao lado deste governo soviético em formação, os chefes da burguesia haviam montado um governo provisório com os destroços da máquina estatal czarista. Eles tentaram, mas não conseguiram desmobilizar os sovietes.

O confronto entre estes dois poderes concentrou-se na alternativa guerra ou paz. Defendendo firmemente o cessar fogo no front, os bolcheviques tiveram de enfrentar, além do governo burguês e dos nostálgicos da velha ordem militar-feudal, o marxista Plekhanov e os demais "social-patriotas", que preconizavam continuar a guerra "até a vitória". Empenhado em comprovar para as massas a necessidade de uma nova revolução que alijasse os belicistas do poder, Lênin publicou no Pravda, com um dia de intervalo, os dois célebres artigos em que formulou a linha política que iria conduzir os bolchevistas à incomparável vitória de outubro. No dia 7 de abril, em "As tarefas do proletariado na presente revolução" (ou "Teses de Abril”, como este texto ficou conhecido mais tarde), ele tirou as consequências de sua constatação fundamental: "O que há de original na situação atual é a transição da primeira etapa da revolução, que deu o poder à burguesia [...] a sua segunda etapa, que deve dar o poder ao proletariado e às camadas pobres do campesinato". No dia 9 de abril, em "A dualidade do poder", ele sustentou que a derrubada do Czar pela revolução de fevereiro de 1917 havia instaurado uma situação inédita de "dualidade do poder": "ao lado[...] do governo da burguesia, formou-se um outro governo [...] são os sovietes dos deputados operários e soldados", o qual, “considerado quanto a sua composição de classe, é uma ditadura revolucionária do proletariado e dos camponeses (sob o uniforme do soldado)" (LÊNIN, 1966, p. 28).

Nos meses seguintes ele consagrou vários artigos à conexão entre guerra e revolução. Um deles, "A solidez de uma corrente depende da solidez de seu elo mais 
aliados ao "Edinstivo" de Plekhanov. Combinada ao firme apoio à reforma agrária, esta luta tenaz contra a guerra foi decisiva para unir os operários aos camponeses, portanto para encadear a etapa burguesa à etapa operário-camponesa da revolução. Assumindo a luta pela paz e pela terra, as duas grandes aspirações da massa camponesa do povo russo, os heróis de Outubro levaram à vitória a palavra de ordem insurrecional: "Todo poder aos sovietes", isto é, à ditadura revolucionária do proletariado e dos camponeses.

Os bolcheviques consideravam os componentes heterodoxos de seu programa e de seus métodos de combate revolucionário um desvio provisório de rota relativamente às perspectivas da revolução proletária internacional anunciada no Manifesto. Os dirigentes soviéticos, tanto quanto os do movimento operário revolucionário europeu, interpretaram a Revolução de Outubro como a confirmação da ortodoxia por meios heterodoxos. Continuaram confiantes em que, rompido o elo mais fraco do imperialismo, o proletariado logo conquistaria o poder nos países economicamente mais avançados: o grande rio da História voltaria a seu curso normal. Em 1918, diante dos levantes do proletariado que abalaram a Europa submergida nos escombros da destruição bélica, era plausível a expectativa de que a revolução socialista nos países capitalistas centrais estivesse na ordem do dia. Lênin não perdeu de vista, entretanto que também estava desencadeada a revolta dos povos coloniais. Tanto assim que, em geral comedido e sóbrio em suas previsões, ele concluiu o discurso de encerramento do Congresso de fundação da Internacional Comunista (Comintern), em 6 de março 1919, com a solene declaração de que estava próxima a hora da fundação da República Mundial dos Sovietes (LÊNIN, 1961b, p. 501). Dezesseis meses depois, em 19 de julho de 1920, Lênin reiterou aquela proclamação no final de seu Relatório sobre a situação internacional apresentado na sessão de abertura do II Congresso da Internacional Comunista: “[...] se nossos camaradas de todos os países nos ajudarem agora a organizar um exército único, nada mais poderá nos impedir de completar nossa obra. Essa obra é a revolução proletária universal, a criação da República universal dos Sovietes" (LÊNIN, 1961b p. 241). 
Enquanto perdurou a mobilização revolucionária do proletariado europeu, cruelmente agredido e dizimado pelas destruições da guerra, mas entusiasmado pelo exemplo da Revolução de Outubro, perdurou também a grandiosa expectativa da proximidade da revolução mundial, suscitada pelo fundador do bolchevismo e da Internacional Comunista. Sem deixar de acompanhar as lutas do proletariado europeu, Lênin assumiu a relatoria da Comissão Nacional e Colonial do II Congresso do Comintern, cujas conclusões ele apresentou em 26 de julho de 1920. Considera a "ideia essencial” das teses da Comissão “a distinção entre os povos oprimidos e os povos opressores". Esta distinção, ausente do vocabulário e do pensamento de Marx e de Engels (já que ela decorre em linha reta da teoria do imperialismo), exprime a mais larga contradição da humanidade:

O traço característico do imperialismo é que o mundo inteiro[...] se divide atualmente num grande número de povos oprimidos e um número ínfimo de povos opressores, que dispõem de riquezas colossais e de uma poderosa força militar. Estimando a população total do globo em um bilhão e três quartos, a imensa maioria, compreendendo muito provavelmente um bilhão duzentos e cinquenta milhões de seres humanos [...], pertence aos povos oprimidos, os quais ou se encontram colocados sob um regime de dependência colonial direta, ou constituem Estados semicoloniais, como a Pérsia, a Turquia, a China [...]. (LÊNIN, 1961c, p. 247-248).

Pressentida por Lênin, quando enfatizou a adesão da "aristocracia operária" dos países imperialistas à ordem burguesa, a concentração nos continentes colonizados dos aspectos mais opressivos da exploração capitalista correspondia a um ponto cego das previsões de Marx e de Engels no Manifesto: a polarização em escala planetária entre o imperialismo e os povos da periferia oprimida. Na visão de Lênin, as linhas de força do avanço revolucionário haviam se ampliado para a periferia colonial, justificando a expectativa de uma revolução em escala mundial.

$\mathrm{Na}$ imensa China, agredida, ultrajada e saqueada ao longo do século XIX pelos traficantes de ópio da City londrina e por seus parceiros franceses, gestou-se uma dinâmica revolucionária comparável por sua profundidade à da Rússia. Em dezembro de 1911, após uma década e meia de revoltas sucessivas, cujo principal inspirador foi Sun 
luta dos partidos na China", publicado no Pravda de 3 de maio de 1913, mostrando estar bem informado em Cracóvia, onde estava residindo, sobre os acontecimentos na China, Lênin sintetizou bem a situação:

\begin{abstract}
“Hoje, quando triunfou a democracia revolucionária, ele (Yuan Shikai) se proclama republicano. Ele se prepara para amanhã se pôr à frente de um Estado novamente monárquico, portanto a trair a república. $O$ partido de Sun Yatsen se apoia sobre o sul da China, isto é, sobre a região a mais evoluída, onde a indústria e o comércio são os mais desenvolvidos [...]. Os partidos que defendem Yuan Shikai apoiam-se sobre o norte atrasado do país. No momento, Yuan Shikai saiu vencedor das primeiras escaramuças [...]"(LÊNIN, 1970, p. 282).
\end{abstract}

Yuan Shikai sairia vencedor também das escaramuças seguintes, graças ao importante "auxílio monetário" que lhe proporcionou um consórcio dos mais poderosos bancos da Inglaterra, França, Alemanha e EUA, preocupados em "fortalecer o poder do governo de fato da China contra as forças que se opõem à lei e à ordem" (alusão pejorativa aos defensores da República democrática proclamada em Nanquim). $\mathrm{O}$ dinheiro adiantado pelos banqueiros permitiu adquirir as armas e os equipamentos bélicos com os quais Yuan Shikai abriria caminho para a ditadura. As condições do empréstimo, que garantiam mais um "negócio da China” para os agiotas do Ocidente, revoltaram os democratas e patriotas chineses. O Kuomintang, partido nacional popular fundado por Sun Yatsen, em julho de 1913, levantou-se de armas na mão contra o usurpador. A guerra foi curta: no início de setembro, com o apoio de tropas britânicas e alemãs e dos chamados "senhores da guerra" feudais, o exército de Pequim tomou os últimos baluartes republicanos. Dono do poder, Yuan Shikai pôs o Kuomintang fora da lei, cassando seus 438 mandatos nas duas câmaras obtidos nas eleições legislativas no final de 1912 e início de 1913. Em 1915, ele se fez proclamar imperador, mas desfrutou por pouco tempo do título. Morreu em 1916. A república foi oficialmente restabelecida por seus herdeiros políticos, nomeadamente o general Duan Qirui, comandante do exército de Pequim, que assumiu o cargo de primeiro ministro, com Li Yuanhong no cargo de 

regiões em que detinham o mando militar.

Mas exatamente por estar fragmentado, o poder de Estado chinês continha brechas, que permitiram a Sun Yatsen, em outubro 1919, à frente do Kuomintang reorganizado, retomar o combate popular contra a submissão às potências imperialistas, pela unidade da China e pelas instituições republicanas. No dia $1^{\circ}$ de julho de 1921 , em Shanghai, ocorreu o Congresso de fundação do Partido Comunista da China, que se aliou ao Kuomintang na vanguarda da luta antifeudal e anti-imperialista. O governo soviético e a Internacional comunista apoiaram firmemente esta aliança nacional-democrática. $\mathrm{Na}$ Mongólia, independente da Rússia e da China imperiais desde 1911, uma revolução popular instaurou em 1921 um governo socialmente avançado, que se aliou à Rússia soviética. Foram estes os primeiros passos da emancipação política dos povos do Oriente.

No momento em que Lênin morreu, a vaga revolucionária que abalara a Europa de 1918 a 1924 acabava de se quebrar de encontro às muralhas da reação. Desfez-se assim a expectativa de uma vitória iminente do proletariado na Europa central e ocidental e consequentemente de uma revolução de dimensões mundiais. As linhas de força revolucionárias concentraram-se na Ásia, principalmente no Oriente asiático, enquanto a República soviética empenhava-se na construção das bases materiais de uma sociedade socialista.

\section{O comunismo na história do século XX}

O curso da história universal ao longo do século XX confirmou a lógica objetiva que fundamenta as teses de Marx e Engels sobre a expansão planetária da burguesia, o caráter historicamente determinado, portanto limitado, das relações capitalistas de produção, a acumulação e concentração da riqueza, a recorrência das crises etc. Sem dúvida, porém, a expectativa de uma revolução proletária nos países onde o capitalismo estava mais desenvolvido não se confirmou. Confirmou-se, entretanto, o papel decisivo 
Teses enunciadas por um pensador de gênio, mesmo quando contêm conclusões não confirmadas pelos fatos, apontam para possibilidades objetivas inscritas na dinâmica histórica. Vimos que no clima otimista do final do século XIX, Engels iludiu-se ao anunciar na Introdução para As lutas de classe na França um “desenvolvimento industrial pacífico". Por antever que confrontos bélicos assumiriam dimensão mundial e "inédita crueldade", ele ponderou que tão catastrófica perspectiva induziria os círculos dirigentes das grandes potências a abster-se da tentação de resolver pela força seus antagonismos. Dezenove anos depois $^{12}$, em 1914, o início da primeira grande mundial desmentiu esta expectativa. A grande carnificina imperialista prolongou-se até 1918, interrompida somente no Leste pela Revolução de Outubro. Em 1939, uma nova guerra mundial, ainda mais mortífera e cruel do que a primeira, com métodos inéditos de extermínio em massa, voltou a desmentir a expectativa de Engels. No epílogo, em agosto de 1945, os estadunidenses pulverizaram em alguns minutos cerca de 200.000 japoneses, lançando a bomba atômica, que tinham acabado de inventar, sobre Hiroshima e Nagasaki. Esta operação de extermínio, a maior de toda a trajetória do homo sapiens (se considerarmos o critério objetivo da quantidade de mortos por unidade de tempo), teria sido provavelmente o prelúdio de outros aniquilamentos nucleares de países que se opunham à Casa Branca e ao Pentágono, se os soviéticos não tivessem rompido em 1949 o monopólio nuclear estadunidense, fabricando eles também bombas atômicas. Só então confirmou-se a parte de verdade da previsão de Engels: o espectro da destruição recíproca exerceu o efeito dissuasivo que ele tinha previsto, mas em condições muito mais sombrias do que teria sido possível imaginar na última década do século XIX.

Continuadores da Revolução de Outubro, os comunistas foram os grandes protagonistas da luta contra o nazifascismo. Defenderam a República espanhola durante a guerra civil de 1936-1939, organizaram a resistência armada dos partisans na Europa ocupada e, nas fileiras do glorioso Exército Vermelho, foram os artífices da grandiosa vitória da União Soviética sobre a Alemanha hitleriana. A imagem da bandeira da foice e

\footnotetext{
${ }^{12}$ A Introdução está datada de 6 de março de 1895, cinco meses antes de sua morte.
} 
Durante as quatro décadas seguintes, até a derrocada do bloco socialista do leste europeu, o confronto estratégico que opôs a União Soviética aos Estados Unidos foi adequadamente caracterizado como equilíbrio do terror nuclear. Ficou mais conhecido, entretanto, pela expressão jornalística "guerra fria". Nunca será demais insistir em que o confronto só foi "frio" no sentido (a) de que não foi nuclear; (b) não opôs diretamente em campo de batalha soviéticos e estadunidenses.

Na Europa, diferentemente do que ocorrera nos levantes proletários de 1918-1924 e nas lutas que em 1936 levaram à formação de governos de Frente Popular na Espanha e na França, os grandes avanços sociais das três primeiras décadas do pós-II Guerra Mundial não foram aniquilados pela contrarrevolução. A forte presença dos partidos comunistas na Itália e na França e a sombra da União Soviética incitavam a burguesia europeia à prudência. Mesmo porque, graças aos dólares do plano Marshall, as combalidas economias do ocidente europeu se soergueram, criando as condições para estabilizar a dominação burguesa através da negociação com o movimento operário dos termos do “Estado de bem-estar social”. Os comunistas marcaram em profundidade a história social e cultural da Itália e da França, mas embora insistindo em que sobre a base das relações capitalistas de produção os direitos sociais conquistados pelos trabalhadores são precários e sujeitos a retrocessos conforme as conjunturas, eles tiveram muita dificuldade política em convencer as massas populares de que era preciso ir adiante. Em Portugal, entretanto, eles participaram decisivamente da revolução dita "dos Cravos", que derrubou em 1974 o regime colonial fascista.

Do outro lado da Eurásia, as guerras anticoloniais, previstas por Lênin, que viu na Revolução de Outubro o preâmbulo da República mundial dos sovietes, estenderam-se até 1975. Em 1949, concluía-se, com a vitória final do Exército Popular conduzido por Mao Tsetung, Chu Enlai e outros grandes dirigentes revolucionários, a Longa Marcha de libertação do povo e do território continental da China. Foi este o momento escolhido pelos Estados Unidos para desencadear, com apoio da submissa ONU, sua contraofensiva planetária, intervindo na Coreia. 
Embora os comunistas coreanos tenham tomado a iniciativa da abertura das hostilidades no dia 25 de junho de 1950, eles apenas reagiram às contínuas provocações e à repressão em massa promovida pelo regime do fâmulo Syngman Rhee, que agia com pleno apoio do general MacArthur, comandante das forças estadunidenses no ExtremoOriente (VADNEY, 1987, pp. 133-148) $)^{13}$.

Batidas no terreno pelos combatentes comunistas, calejados na guerra de guerrilhas, as tropas de Syngman Rhee só escaparam da completa derrota pela prontíssima intervenção (dois dias depois) do dispositivo bélico do general MacArthur. Contando com a falta de disposição dos soviéticos para intervir diretamente (eles ainda se ressentiam do colossal esforço de guerra de 1941-1945), as tropas de MacArthur conseguiram reverter a situação ao desembarcarem, em Inchon, na altura de Seul, no dia 15 de setembro. Confirmando subserviência aos Estados Unidos, a ONU votou, no dia 7 de outubro, uma resolução autorizando MacArthur a cruzar o paralelo 38 (que dividia as duas Coreias) e avançar rumo ao norte, rompendo as linhas de defesa dos patriotas coreanos. Desprezando as advertências da China para que não se aproximasse de sua fronteira chinesa, o garboso general para lá encaminhou suas tropas. O Exército Popular Chinês, que o esperava às margens do rio Yalu, desfechou uma fulminante contraofensiva à qual os norte-americanos responderam com rápida debandada. Em 30 de novembro de 1950, confirmando ameaças reiteradamente brandidas pelo general MacArthur, que o rancor do fiasco tornara ainda mais sedento de holocaustos, o presidente Truman admitiu, em entrevista à imprensa, a possibilidade de recorrer novamente à bomba atômica, desta vez contra os chineses. Dentre os fatores que detiveram a tentação genocida, o principal foi a referida quebra do monopólio norte-americano da arma nuclear: desde o ano anterior, a União Soviética dispunha também da bomba atômica. Contribuiu também para impedir que Truman passasse das palavras aos atos a firme atitude do primeiro ministro britânico, o trabalhista Clement Attlee. Numa atitude oposta à que adotaria meio século depois o ignóbil Blair, cúmplice de todas as operações genocidas de G. W. Bush, ele deslocou-se para Washington a fim de obter de Truman

\footnotetext{
13 Segundo Vadney (1987, p. 142), em agosto de 1949, em consequência da repressão promovida pelo regime policial de Syngman Rhee, havia na Coreia do Sul cerca de 36.000 prisioneiros políticos
} 
MacArthur e, como este persistisse em preconizar o emprego da bomba atômica na Coreia e na própria China, destituiu-o do comando das forças estadunidenses.

Naquela tenebrosa encruzilhada histórica, a máquina bélica estadunidense absteve-se do emprego da arma nuclear, mas não de calcinar, entre 1950 e 1953, cerca de $80 \%$ das cidades e aldeias norte-coreanas (as estatísticas oficiais da US Air Force admitem terem sido lançadas sobre a Coreia do Norte, durante os trinta e sete meses do confronto bélico, 454000 toneladas de bombas, principalmente de napalm); o cessar fogo de 1953 cristalizou a atual divisão da Coreia entre um norte independente e um sul sob tutela estadunidense.

Também no Vietnã, a perversa dialética da chantagem nuclear inibiu o recurso às armas nucleares, mas não a inventividade letal dos genocidas do Pentágono, que despejaram sobre cidades, campos e matas, durante mais de uma década, uma horripilante tempestade de fogo, chumbo e materiais tóxicos. Ainda hoje, meio século depois da expulsão final dos invasores, ainda nascem no Vietnã crianças deformadas ou mutiladas pelo "agente laranja", desfolhante ultra tóxico à base de dioxina com efeitos de longa duração, lançado pela US Air Force sobre plantações e florestas para envenenar a população e carbonizar as árvores. Estas e outras atrocidades não impediram o heroico povo vietnamita, sob a direção de Ho-Chi-Min e de Giap, de levar adiante a guerra de libertação nacional, infligindo aos invasores estadunidenses uma derrota militar completa que culminou em abril de 1975, com a entrada em Saigon, hoje cidade Ho-Chi-Min, dos combatentes da Frente Nacional de Libertação (FNL).

Abril de 1974 em Portugal, abril de 1975 no Vietnã foram as duas últimas vitórias da luta revolucionária conduzida pelos continuadores de Outubro de 1917. Por mais sombrias que sejam as consequências dos retrocessos sociais, eles ao menos permitem aquilatar o que foi perdido desde então. Basta comparar com a de hoje a Europa como ela era até 1979, quando a ultra reacionária Margaret Thatcher empreendeu fria e obstinadamente a destruição do “Welfare State” implantado na Grã-Bretanha a partir de 
1945 pelo governo trabalhista de esquerda de Clement Attlee. Thatcher transpôs para o centro do bloco imperialista a contrarrevolução neoliberal preconizada por Hayek e consortes da "escola de Chicago", que já vinha sendo implantada no Chile pelos "Chicago boys", sob as botas de Pinochet. Logo em seguida, em 1980, o macarthista R. Reagan, eleito presidente do Império estadunidense, aplicou a mesma política. No continente europeu, a derrocada do bloco soviético em 1989-1991 facilitou novos ataques ao "Welfare State", com o objetivo último de promover o retorno à situação social da "Belle Époque", anulando, umas depois das outras, as conquistas operárias inspiradas e encorajadas pela Revolução de Outubro. A história não se repete, mas a humanidade carece hoje de um abalo semelhante ao de Outubro de 1917.

\section{Referências}

CORTESI, Luigi. Lenin e il problema dello Stato. In: LOSURDO,Domenico ; GIACOMINI,Ruggero,(Orgs). Lenin e il Novecento. Napoli: La Città del Sole, 1997, p. 241311.

CROCE,Benedett. Frammenti di etica. In: CROCE,Benedett. Etica e politica. Bari, Laterza, 1967.

ENGELS, Introdução de 1895 a KARL MARX. Les luttes de classe en France. Paris: Éditions Sociales, 1974.

GRAMSCI, Antonio. La Rivoluzione contro il Capitale. Avanti, 24 de nov. de 1917. Consultado no Archivio Gramsci da Internet.

LAPOUGE, Gilles. Jospin arrasa hipocrisia francesa de 80 anos. 0 Estado de São Paulo, 8 de nov. de 1998.

LÊNIN, Vladimir. Notas críticas sobre a questão nacional. In: LÊNIN, Vladimir. Oeuvres: volume 20. Paris: Éditions Sociales ; Moscou: du Progrès, 1959a. p.9-45.

LÊNIN, Vladimir. Imperialismo, estágio superior do capitalismo. In: LÊNIN, Vladimir.

Oeuvres: volume 22. Paris: Éditions Sociales ; Moscou: Du Progrès, 1960a. p. 201-327.

LÊNIN, Vladimir. O desenvolvimento do capitalismo na Rússia. In: LÊNIN, Vladimir.

Oeuvres: volume 3. Paris: Éditions Sociales; Moscou: du Progrès, 1969. p. 9-645. 
LÊNIN, Vladimir. O oportunismo e a falência da II internacional. In: LÊNIN, Vladimir.

Oeuvres: volume 22. Paris: Éditions Sociales ; Moscou: du Progrès, 196ob.p. 115-128.

LÊNIN, Vladimir. O programa militar da revolução proletária. In: LÊNIN, Vladimir. Oeuvres, volume 23, Paris-Moscou: Éditions Sociales/du Progrès, 1959b, p. 84-96

LÊNIN, Vladimir. Qual herança renegamos?. In: LÊNIN, Vladimir. Oeuvres: volume 2. Paris: Éditions Sociales; Moscou: du Progrès, 1966c. p. 505-551.

LÊNIN, Vladimir. Que fazer? In: LÊNIN, Vladimir. Oeuvres: volume 5. Paris: Éditions Sociales ; Moscou: du Progrès, 1965. p. 355-544.

LÊNIN, Vladimir. Sobre a dualidade do poder. In: LÊNIN, Vladimir. Oeuvres: volume 24, Paris-Moscou: Éditions Sociales/du Progrès, 1966a, p. 28-31.

LÊNIN, Vladimir. As tarefas do proletariado na presente revolução. In: LÊNIN, Vladimir.

Oeuvres: volume 24. Paris: Éditions Sociales; Moscou: du Progrès, 1966b. p. 47-81.

LÊNIN, Vladimir. Discurso de encerramento do Congresso de fundação da Internacional Comunista. In: LÊNIN, Vladimir. Oeuvres: volume 28. Paris: Éditions Sociales ; Moscou: du Progrès, 1961a, p. 501.

LÊNIN, Vladimir. Relatório sobre a situação internacional (19 de julho de 1920). In: LÊNIN, Vladimir. Oeuvres: volume 31. Paris: Éditions Sociales; Moscou: du Progrès, 1961b. p. 221241.

LÊNIN, Vladimir. Relatório da Comissão Nacional e Colonial. II Congresso da Internacional Comunista. In: LÊNIN, Vladimir. Oeuvres: volume 31. Paris: Éditions Sociales; Moscou: du Progrès, 1961c. p. 247-253.

LÊNIN, Vladimir. A luta dos partidos na China. In: LÊNIN, Vladimir. Oeuvres: volume 41. Paris: Éditions Sociales ; Moscou: du Progrès, 1970. p. 281-283.

LOSURDO, Domenico. O liberalismo entre civilização e barbárie. São Paulo: Anita Garibaldi, 2006.

MARX, Karl. La guerre civile en France.Paris : Éditions Sociales, 1968.

MARX, Karl. Resposta a Mikhailovsky. In: MARX, Karl. Oeuvres: vol. II. Tradução de Maximilien Rubel. Paris: Gallimard, 1968. p. 1552-1555. 
MARX, Kar; ENGELS Friedrich. Manifest der Kommunistischen Partei. Ausgewählte Werke in sechs Bänden, Band 1. Berlin: Dietz Verlag, 1978. p. 383-451.

MARX,Karl; ENGELS Friedrich. Correspondência com Vera Zasulich. Correspondance. Moscou: Éditions du Progrès, 1971. p. 349-350.

MORAES, João Quartim de. Lenin e il Novecento. Crítica Marxista, São Paulo n. 10, p. 133$145,2000$.

MORAES, João Quartim de. Apresentação de o socialismo francês em 1900: o grande debate entre Jean Jaurès e Jules Guesde". Crítica Marxista, São Paulo, n. 24, p. 139-141, 2007.

O'CONNOR, James. The meaning of economic imperialism. In: RHODES, Robert I. (Org.). Imperialism and underdevelopment. Londres, Nova lorque: Monthly Review Press, 1970.

VADNEY, Thomas. The World since 1945. Londres: Penguin Books, 1987. 